\title{
Developing Reading Competencies of College Students Using Blended Instruction
}

\author{
Katherine B. Akut \\ Bukidnon State University, Malaybalay City, Philippines \\ akutkatherine@gmail.com \\ Hazel Jean M. Abejuela, PhD \\ Bukidnon State University, Malaybalay City, Philippines
}

DOI: https://doi.org/10.36892/ijlls.v2i3.348

\begin{tabular}{|c|c|}
\hline $\begin{array}{l}\text { Received: } \\
\text { 04/07/2020 }\end{array}$ & $\begin{array}{l}\text { Abstract } \\
\text { Developing 21st-century reading competencies is one of the primary concerns }\end{array}$ \\
\hline $\begin{array}{l}\text { Accepted: } \\
\text { 14/09/2020 }\end{array}$ & $\begin{array}{l}\text { of higher education institutions }(H E I s) \text {. Initiatives have been undertaken to } \\
\text { prepare the learners to function effectively in this technology-driven society. } \\
\text { Hence, academic institutions integrate technology and the Internet in the }\end{array}$ \\
\hline $\begin{array}{l}\text { Keywords: } \\
\text { Blended learning; } \\
\text { hypertext readin; } \\
\text { 21st-century learning; } \\
\text { reading competencies. }\end{array}$ & $\begin{array}{l}\text { teaching-learning processes. This study intends to determine the effectiveness } \\
\text { of instructional material on developing reading competencies using blended } \\
\text { instruction. Dziuban, Hartman and Moskal, (2004) define blended instruction } \\
\text { as a pedagogical approach that integrates the effectiveness and socialization } \\
\text { opportunities of the classroom with the technologically enhanced active } \\
\text { learning possibilities of the online environment. Six lessons were implemented } \\
\text { in the English } 107 \text { - College Reading Skills classes. The learners were } \\
\text { provided with hypertext reading activities, individual and collaborative tasks, } \\
\text { online discussions, online surveys and other extension activities which } \\
\text { provided them with the opportunity to communicate their ideas on the topics } \\
\text { discussed in class. To determine the effectiveness of the lessons, a one-group } \\
\text { pretest and post-test design was used. The pre-test and post-test scores were } \\
\text { compared using the paired t-test. Findings reveal that the students performed } \\
\text { better after the implementation of the lessons in developing reading } \\
\text { competencies using blended instruction. Moreover, the majority of the } \\
\text { students said that the lessons are interesting, meaningful, useful and } \\
\text { enjoyable. It can be concluded that blended instruction effectively develops the } \\
\text { students' reading competencies. }\end{array}$ \\
\hline
\end{tabular}

\section{INTRODUCTION}

One of the primary concerns of higher education institutions (HEIs) is to ensure that learners develop the reading competencies necessary for the $21^{\text {st }}$-century academic and workplace demands. Competence in processing both printed and electronic texts is necessary to meet the demands of global competitiveness in the academe and the workplace. Hence, educators are continually exploring ways to respond to the call of globalization. Initiatives are undertaken to facilitate the development of relevant outcomes that would make the graduates of HEIs fully equipped for the global workforce.

However, the country is still in dire need for graduates who are fully prepared for the international labor market and who are adequately skilled in using modern-day technologies. The People Management Association of the Philippines (PMAP) revealed that 4 out of 10 fresh graduates and young applicants are not hired because they are deficient in three key qualities; critical thinking, initiative and effective communication skills. Rosero (2012) further stressed that soft skills include solving actual workplace problems, taking action 
without being told and communicating effectively in the language of business (Rosero, 2012). This signifies a growing demand for developing advanced competencies which are prerequisite to the workplace and academic success in the twenty-first century (Lesaux, 2012; Murnane, Sawhill, \& Snow, 2012).

The preceding concerns on the reading proficiency levels of job applicants necessitate the use of innovative strategies in teaching reading. It can be noted, however, that at present, there is an inadequate number of materials for college reading that integrate both printed and online materials in developing comprehension skills. This study, therefore, aimed to test the effectiveness of blended learning in developing the reading competencies of college students. It specifically aimed at designing reading activities that help the students of the College of Business to access information from different sources and process this information using higher-order thinking skills. The activities are expected to develop the reading skills needed to process reading materials not only from the traditional printed texts but also those that are accessed from the Internet.

\section{FRAMEWORK OF THE STUDY}

The concept of Blended Instruction serves as the basis of this study. Dziuban, Hartman and Moskal, (2004) define blended instruction as a pedagogical approach that integrates the effectiveness and socialization opportunities of the classroom with the technologically enhanced active learning possibilities of the online environment. This approach includes incorporating both face to face teaching and ICT in the teaching-learning process. Furthermore, blended learning combines direct instruction, indirect instruction, collaborative teaching, individualized computer-assisted learning (Lalima \& Dangwal, 2017).

In this study, the lessons consist of face to face teaching, student interaction with course content, peer group interaction, online group discussion and exchange of ideas and hypertext reading activities. Hypertext reading refers to the mode of reading which requires readers to click electronic linking of texts found on the internet (Patterson,2000). Wang (2012) maintains that reading and comprehending hypertexts are vital skills for students to obtain knowledge and skills in the $21^{\text {st }}$ century. According to Salmeron, Kintsch, and Cañas (2006), in comprehending hypertexts, the same cognitive processes involved in reading a traditional linear text are required. However, hypertext involves an additional cognitive process. This is the process of selecting the reading order of the text sections. Unlike reading a printed material in which readers rely on the linear structure, hypertexts necessitate readers to follow different strategies to select articles to be read. (Salmeron, Kintsch, \& Cañas, 2006).

Dail (2004) presents hypertext reading strategies commonly used by learners. These include scrolling the document, skimming the text, note-taking by hand, summarizing information, and relying on prior knowledge. Foltz (1996) also specifies reading strategies that are used by readers when processing hypertexts. Reading hypertexts involves determining specific information that matches reading goals to the possible nodes, identifying relevant nodes of the text reading and selecting the appropriate node that provides the information they need.

Leu, McVerry, O’Byrne, Kiili, Zawilinski, Cacopardo, Kennedy and Forzani (2011) specify the following recursive reading practices which require comprehension skills to process hypertexts. The first reading skill is identifying important questions. This requires identifying the purpose of reading as the central aspect of reading online texts. The second reading skill is locating information that meets one's needs. This requires formulating effective keyword search strategies; reading and inferring useful links, and efficiently identifying relevant information within the website. The third skill is reading to critically 
evaluate information. Readers examine whether the information from the internet is accurate and reliable. The fourth skill requires synthesizing online information from different sources and format. Lastly, the fifth reading skill is to communicate information through the internet. This refers to the learners' ability to read and communicate ideas on the internet through online discussions, texting, blogs, wikis, videos, shared writing spaces and social networks.

Wang (2012) recommends that learners should be taught reading comprehension strategies to enhance students' hypertext comprehension performance. These strategies are categorized into cognitive strategies, metacognitive strategies and socio-affective strategies. Cognitive strategies include rehearsal or repeating what is read, organization which involves grouping and classifying ideas, making inferences, summarizing, deducing information, using visual images to remember new information learned, using new information in new reading tasks and linking ideas contained in new information.

Metacognitive strategies, on the other hand, involves selecting key aspects of reading materials based on purposes of reading; planning the organization of the written discourse; monitoring comprehension processes; and evaluating what has been read and checking if comprehension occurs. Socio-affective strategies are working with peers to solve problems and getting feedback from them; seeking clarification from teachers and self-talking to control one's own reading processes and reduce anxiety (O'Malley \& Chamot,1990). Wang (2012) suggests that it is necessary to provide hypertext reading comprehension exercises that require learners to apply the strategies taught classroom. These activities should be given to students after the strategy instruction in every session, so that participants are able to remember strategies taught in the class as they read independently.

\section{Statement of the problem}

This study aims to determine the effectiveness of instructional material on developing reading competencies using blended instruction. It specifically intends to answer the questions:

1. Is there a significant improvement in the reading performance of the students after the try-out of the lessons on developing reading competencies of learners using blended instruction?

2. What are the students' opinion regarding the lessons on developing reading competencies of learners using Blended instruction?

\section{METHODOLOGY}

This quasi-experimental study was conducted among the second-year college students of Bukidnon State University, Malaybalay City, Bukidnon, Philippines. Four sections with a total of 159 Second Year students enrolled in the subject English 107 - College Reading Skills serve as the try-out group.

To determine the effectiveness of blended learning activities, six lessons were tried out in the English 107 - College Reading Skills classes. Prior to the try-out of the lessons, a 30 -item pretest was administered. Then, the students were provided with lessons and activities which were divided into 3 stages, the Into, Through and Beyond reading activities. They were also exposed to hypertext reading activities, individual and collaborative tasks, online discussions, online surveys and other extension activities which provided them with the opportunity to communicate their ideas on the topics discussed in class. After the try-out, another 30-item post-test was administered. Using the paired t-test, the pretest and post-test scores of the students served a means of comparison to determine whether there is a significant difference in the performance of the students.

After the try-out, the participants were also given copies of the opinionnaire and they were asked to rate the activities based on (a) interest, (b) appeal (c)acceptability, (d) 
relevance of the material. They were also requested to write their comments and suggestions regarding blended learning activities. Table 1 shows the interpretation scale used.

Table 1. Interpretation Scale for the Characteristics of the Activities (Student-Users' Opinion)

\begin{tabular}{ccc} 
Description & Rating & Interpretation \\
Yes & 1 & Activities are interesting, meaningful, useful and enjoyable \\
\hline No & 0 & Activities are not interesting, meaningful, useful and \\
& & enjoyable
\end{tabular}

The student-users evaluated the activities using this dichotomous (two-point) scale with yes-no responses. If they found the lessons interesting, meaningful, useful and enjoyable, their answer was yes. On the other hand, if they did not find the activities interesting, meaningful, useful and enjoyable, they answered no. The dichotomous or twopoint scale can yield significant information as it ensures that students do not choose the neutral response. Instead, the students are able to provide the exact responses whether they liked the activities or not. (Clark \& Watson, 1995; Sincero, 2012).

\section{RESULTS AND DISCUSSION}

\section{The Effectiveness of Blended Instruction}

The test of the effectiveness of the lessons was done by administering pre- and posttests. Using the paired t-test, the scores of the students served as means of comparison to determine whether there is a significant difference in the performance of the students. Prior to the try-out of the material, a 30-item pre-test was administered. As can be ascertained Table 2 , the scores of the students increased in the post-test as evident in the mean.

Table 2. Reading Comprehension Skills Pre and Post Test Results

\begin{tabular}{lllc} 
Means of Comparison & $\mathrm{N}$ & Mean & s.d. \\
Pre-test & 158 & 17.348 & 4.627 \\
\hline Post-test & 158 & 21.513 & 3.678 \\
& & & \\
\hline Mean Difference & & 4.165 & 4.035 \\
\hline
\end{tabular}

Test of Comparison between Pre-test and Post-test p-value $=0.000^{*}$

*Significant at 0.05 level t-value $=12.97$

Findings reveal that the students performed better after the implementation of the lessons in developing reading competencies using blended instruction. It can be further deduced from the means obtained that the scores of the students during the pre-test ranged from $7-24$ out of the 30 items. This indicates that many of the students have low reading proficiency level and that the reading comprehension skills identified were least mastered. On the contrary, the students' score during the post-test ranged from 13 - 30 out of the 30 items. 
This implies that the activities developed can enhance the reading competencies of the students effectively.

The findings of Salmeron, Kintsch and Cañas (2006) support the findings of the effectiveness of the integration of hypertexts in the activities. Based on their experimental research, learners benefited from the hypertext reading in comparison to linear printed text reading. This, however, is dependent on the prior knowledge of the learners before they are required to read hypertexts. Their findings further reveal that students with different reading proficiency levels use different strategies in selecting hypertexts to read. It suggests that students should be given enough practise in selecting and evaluating sources of information. Hence, it is important that students are provided with exercises that will develop their abilities in reading, analyzing and evaluating source of information both for printed and online texts.

In another recent study, Shang (2015) found significant results in the use of hypertext in combination with teacher-guided print based learning. In addition, Shang also found the positive response and interest of the learners towards the use of hypertext in their reading activities although the degree of usefulness of hypertext reading was not established. It can be deduced that hypertext reading could be used to supplement print based reading activities in order to achieve optimal reading performance among the students.

\section{Students' Opinion regarding Blended Learning}

After the implementation of the lessons, the students expressed their opinion whether the activities were interesting, meaningful, useful and enjoyable. As disclosed in the table 3, majority of the students responded to the indicators with a yes as manifested in the over-all percentage of the students who find the activities interesting, meaningful, useful and enjoyable.

Table 3. Summary of the Students' Evaluation of the Lessons

\begin{tabular}{lll}
\hline \multicolumn{1}{c}{ Features } & $\mathrm{N}$ & $\%$ \\
\hline 1. The activities are challenging but interesting. & 151 & 99 \\
\hline 2. The activities allow me to actively read selections with & 150 & 98 \\
comprehension. & & \\
\hline 3. The activities made pair and group works enjoyable to do. & 144 & 94 \\
\hline 4. The presentation of the activities makes learning interesting. & 151 & 99 \\
\hline 5. The language used and the visuals like pictures, cartoons and & 124 & 81 \\
$\begin{array}{l}\text { graphic organizers provide ease in learning the } \\
\text { 6. content. }\end{array}$ & 116 & 76 \\
\hline 7. The graphic and illustrations are attractive and inviting. & 148 & 97 \\
\hline 8. The directions/instructions of the activities are easy to follow. & 152 & 99 \\
\hline 9. The reading materials present business-related topics/concepts. & 149 & 97 \\
\hline 10. The activities help me understand business-related words and \\
$\quad$ expressions.
\end{tabular}


skills both in printed and online form.

15. Through the activities, I learned to communicate my ideas $\quad 136 \quad 89$ through web forums and online discussions.

16. The activities enhanced my reading and communication skills $\quad 140 \quad 92$ required in online discussion, email, video, shared writing spaces and social networks.

Among the fifteen indicators, three items got the highest percentage (Items 8, 1 and 4). These items provide that that the instructions are easy to follow, the activities are challenging but interesting and the presentation of the activities make learning interesting. It can be drawn from the table that $99 \%$ of the students agreed that the reading materials are all business-related. This is confirmed by unedited comments of one of the student-users as shown in Frame 1.

The topic that we tackle are quite interesting and we learn a lot of things and we enhance our reading and communication skills in online discussion. And we are able to develop our reading comprehension via Internet resources and the topics are totally related to our course.

\section{Frame 1}

The student's comment shown in Frame 1 also relates with another indicator expressing that the activities are challenging but interesting. This obtained the rating of $99 \%$. This is further confirmed by another student-user whose comment appears in Frame 2.

I learned a lot from the lessons that we tackled. Few of them are a little bit hard and challenging, but I'm thankful because it pursue me to study the lesson not just to get grades but also to understand it very well. I like it when we had the activities about the online discussion because we shared ideas about a certain topic and all of us enjoyed it.

\section{Frame 2}

This implies that the students put premium on the interest value and the relevance of lessons. The integration of activities such as online discussion aside from the usual classroom tasks ma lessons more enjoyable for the learners. Also, the relevance of the lesson can also be attributed to the use of business-related texts. As pointed out by Chávez (1998), students' motivation is enhanced with the use of authentic materials relevant to their academic fields.

Lastly, the results also revealed that the majority of the students agree that the presentation of the activities makes learning interesting. This can be due to the fact that the activities involved not only printed texts but also hypertexts. In terms of tasks, the material provides opportunities for students to interact with others through individual, pair and group activities done both inside the classroom and through the Internet. This result is also supported by one of the comments of the students as shown in Frame 3 on the next page. 
The topics are interesting especially the online discussion because you can express your ideas and opinion confidently.

\section{Frame 3}

With the student's comment above, it is apparent that the online discussion interests the learners because it is less threatening for them. In other words, they are more confident to express their ideas online in an actual classroom setting. One reason for this is the fact that students can reread several times the reading material before presenting their opinion. Moreover, in an online discussion, they always have enough time to review and edit their responses, unlike actual classroom discussions. Thus, the findings affirmed the findings of Enriquez (2014) that the majority of the participants considered online learning platforms as an effective and interesting supplementary tool for their learning. Similarly, Warchauer (1996) also found that the use of the Internet in combination with creative and collaborative activities increase motivation and participation among the students.

Among the indicators, the items pertaining to the language used, the graphic organizers, pictures, illustrations and cartoons obtained the lowest rating. In other words, a number of students did not find these elements attractive and inviting. This may be due to the fact that the worksheets were reproduced by photocopying. This is confirmed by the student's comment in Frame 4.

Sometimes the visual like pictures that can be found in the handout can't be clearly seen because of the black and white color.

\section{Frame 4}

This comment again reaffirms the contention of Howard and Major (2005) that one of the important components of designing instructional materials in English is the appearance. Attractive and colorful pages would create a positive initial impression of the learners towards the materials. This is deemed important in motivating them to learn. Nunan (1991) stresses that in designing instructional materials, the appearance is among the important factors to consider. These include colorful, attractive and interesting graphics that supplement written texts.

\section{CONCLUSION AND RECOMMENDATION}

It can be concluded that the lessons blended instruction are effective in developing the students' reading competencies. Furthermore, the reading materials that are disciplinespecific that can be accessed in printed and online forms make learning more interesting and enjoyable for the learners. The integration of online activities to the traditional classroom tasks motivates the learners to participate in collaborative classroom and web-based tasks. It is therefore recommended that blended instruction using discipline-specific texts and hypertext reading activities be integrated in the 21 st century classrooms.

\section{REFERENCES}

Alexander, P.A. \& Jetton, T.L. (2000). Learning from text: A multidimensional and developmental perspective. Handbook of reading research, 3, 285-310. 
Ambrona, C.L. (2011). Activities to develop critical reading skills. Unpublished Master's Thesis. Bukidnon State University. Malaybalay City.

Amiri, M. \& Fatemi, H. (2014).The impact of content-based instruction on students' achievement in ESP courses and their language learning orientation. Theory And Practice In Language Studies, Vol. 4, No. 10, pp. 2157-2167, October 2014. Finland: Academy Publisher. Retrieved from: http://www.academypublication.com/issues/past/tpls/vol04/10/24.pdf

Bayraktar, H. (2005). A communicative competence perspective on difficulties in 12 reading. Published Master's Thesis, Middle East Technical University. Retrieved from: http://etd.lib.metu.edu.tr/upload/12606279/index.pdf

Brinton, D. M., Snow, M. A., \& Wesche, M. B.(1989). Content-based second language instruction.Boston: Heinle and Heinle.

Brown, J. (2014). A content-based model for developing critical thinking and language skills in EAP1. Retrieved from: http://www.camtesol.org/Download/LEiA_Vol5_Iss2_2014/LEiA_ V5_I2_A08_Brown_Content_Based_Model_Critical_Thinking_EAP.pdf

Cabasan, H.C. (2011). The reading comprehension levels of freshman education students: A reading program design. International Journal of Arts \& Sciences, CD-ROM. ISSN: 1944-6934 :: 4(18):357-363 (2011) by InternationalJournal.org Retrieved from: http://www.openaccesslibrary.org/images/0418_Haydee_C._Cabasan.pdf

Chen, N. S., Teng, D. C. E., Lee, C. H., \& Kinshuk. (2011). Augmenting paper-based reading activity with direct access to digital materials and scaffolded questioning. Computers \& Education, 57, 1705-1715.

Consad, R.R (2014). E-games and linguistic intelligence on students' receptive skills.

Published Dissertation. Cebu Normal University, Cebu City.

Dail, J. S.(2003).Reading in an online hypertext environment: A case study of Tenth-grade English students. Electronic Theses, Treatises and Dissertations. Paper 857.

Davies, S. (2003). Content Based Instruction in EFL Contexts. The Internet. TESL Journal, Vol. IX, No. 2, February 2003.

Dangwal Kiran L.: (2004) Computers in Teaching and Learning:Shre Vinod Pustak Manir, Agra [10]

Dangwal Kiran L.: (2013) Computers Shiksha: Vedant Publication: Lucknow [11] Duzer, J.V. (2002)

Epic (2009a) White Paper - Blended Learning [13] Epic (2009b) White Paper - Blended Learning in practice

Glenn, O. M. (2005). The development of English literacy and global studies concepts using sheltered instruction. Dissertation Abstracts International. (UMI No. 3166569). 
Howard, J. and Major, J. (2005) Guidelines for Designing Effective English language Teacher materials. Retrieved from:

http://www.paaljapan.org/resources/proceedings/PAAL9/pdf/Howard.pdf

Kasper, L, F. (2000). Content-based college ESL instruction. Mahwah, NJ: Lawrence Erlbaum Associates.

Madrona, M. (2014). Activities on developing higher order reading comprehension skills in grade V through scaffolded reading experience. Unpublished Master's Thesis. Bukidnon State University. Malaybalay City

McNamara, D. (Ed.) (2007). Reading comprehension strategies: Theories, interventions, and technologies. New York, NY: Taylor and Francis.

Padagas, B.(2015). A supplementary material in teaching English using digital videos on climate change concepts. Unpublished Master's Thesis. Bukidnon State University, Malaybalay City

Parkinson, J. (2000). Acquiring scientific literacy through content and genre: A theme-based language course for science students. English for Specific Purposes,19, 369-387.

Rosero, E.V. L. (2012, March 3) .Why many fresh college grads don't get hired, according to survey of managers. GMA News. Retrieved from: http://www.gmanetwork.com/news/story/250239/ money/economy/why-manyfresh-college-grads-don-t-get-hired-according-to-survey-ofmanagers\#sthash.6OBBvDzl.dpuf

Salmeron, L, Canas, J.J, Kintsch, W \& Fajardo, I (2005). 'Reading strategies and Hypertext comprehension', Discourse Processes, vol. 40, no. 3, pp. 171- 191.

Salmeron, L., Kintsch, W., \& Cañas, J. (2006) Reading strategies and prior knowledge in learning from hypertext. Memory \& Cognition. 34(5) 1157-1171

Tsai, Y. \& Shang, H. (2010). The impact of content-based language instruction on EFL students' reading performance . Asian Social Science. Retrieved from: www.ccsenet.org

Wang, H. (2012). The influence of comprehension strategies on hypertext reading by students from non-English speaking backgrounds. A Published Dissertation. Swinburne University of Technology. Retrieved from: http://researchbank.swinburne.edu.au/vital/access/services/Download/swin:30748/SO URCE1

Warschauer, M. (1996). Motivational aspects of using computers for writing and communications. In telecollaboration in foreign language learning, ed. M. Warschauer. Honolulu, HI:Second Language Teaching and CurriculumCenter, University of Hawaii Press 


\section{$\underline{A U T H O R S}$ 'BIO}

Katherine B. Akut holds a degree in Master of Arts in English Language Teaching and Bachelor of Secondary Education major in English from Bukidnon State University where is also currently working as a lecturer of undergraduate and graduate courses She is currently a PhD English Language candidate at the University of San Jose-Recoletos, Cebu City. Her areas of interest are instructional materials development, syntax and morphology, and pragmatics.

Hazel Jean M. Abejuela holds a Doctor of Philosophy in Applied Linguistics from De La Salle University-Manila and a master's degree in English Language Teaching from Bukidnon State University. She teaches undergraduate and graduate courses including English for Academic and Professional Communication. She is an active researcher in the field of English and Applied Linguistics with interests in English for Specific Purposes, Discourse Analysis and Ethnolinguistic Studies. 